\title{
Radykalna myśl polityczna a bezpieczeństwo europejskich demokracji. Przykład nacjonalizmu antysystemowego
}

„Myśl polityczna” jest refleksją w sferze polityki. Mogą nią być proste pomysły, postulaty i hasła, a także koncepcje ładu społecznego oraz ideologie, doktryny i programy. To projekty, które mają związek z praktyczną działalnością polityczną i są planem uprawiania polityki. To wreszcie wszelkie wyartykułowane pojęciowo wypowiedzi dotyczące sfery polityki (Paruch, 1999, s. 27-39).

„Radykalizm” - od łacińskiego słowa radix - oznacza powrót do korzeni, a więc do źródeł pojęć, które stosowane są w języku polityki, ale które zostały wypaczone albo są interpretowane jako wypaczone, lub które nie są interpretowane dosłownie. Radykalizm oznacza także brak możliwości kompromisu pomiędzy różnymi grupami społecznymi, które mają różne interesy i realizując je zniekształcają takie pojęcia, jak np. demokracja. Oznacza zatem maksymalistyczne pojmowanie wartości nadrzędnych w określonych nurtach myśli politycznej. W nacjonalizmie wartościami takimi są naród i państwo narodowe. To pojęcia absolutyzowane, których interpretacja nie pozwala na kompromis.

Radykalna myśl polityczna wiąże się z krytyką „tego, co jest” w wymiarze substancjalistycznym. Dotyczy zatem esencji (substancji, istoty) krytykowanego przedmiotu. Krytyka demokracji oznacza zetem jej negację, odrzucenie i konieczność anihilacji. To odróżnia substancjalizm krytyki od krytyki akcydentalistycznej, która w krytykowanym przedmiocie dostrzega zło „wypadkowe”, „niekonieczne”, możliwe do naprawy i nie podważa istoty oraz zasad stanowiących fundament krytykowanego przedmiotu (Bartyzel, 2009).

Analiza myśli politycznej nie jest możliwa bez refleksji nad formami jej wyrażania i podmiotami ją wyrażającymi. Zarówno podmioty wyrażające myśl, jak i formy jej wyrazu, stanowią podstawę refleksji nad samą myślą, która nie powstaje i nie dzieje się w próżni i w oderwaniu od podmiotu ją wyrażającego. Stąd tak ważne w deskrypcji i analizie myśli politycznej są partie polityczne i ruchy społeczne, które są jej „nośnikiem”. Partie polityczne stanowią zorganizowane grupy dążące do zdobycia lub utrzymania władzy, zaś ruchy społeczne to ,akcje zbiorowe zmierzające do wywołania lub powstrzymania zmiany społecznej" (Sztompka, 2005, s. 176), albo świadome zbiorowe dążenie i zespołowa działalność ludzi zmierzających do osiągnięcia wspólnego celu (Olszewski, 2000, s. 331). Jednakże myśl polityczna może być wyrażana także przez polityków, publicystów, dziennikarzy, artystów, w tym pisarzy, wokalistów i malarzy. Ich poglądy determinują bowiem ich aktywność, a ta jest przejawem myśli politycznej.

Myśl polityczna partii i ruchów radykalnych analizowana łącznie z przejawami ich aktywności, która może przybierać formę ekstremizmu, może wpływać na bez- 
pieczeństwo współczesnych państw. Bezpieczeństwo może być rozumiane jako wolność od potencjalnych lub realnych zagrożeń, niezakłócony byt oraz rozwój człowieka i społeczeństw, a także jako nadrzędna potrzeba i wartość oraz konfiguracja sytuacji, zdarzeń, faktów, stanów zależnych i niezależnych od ludzi (Kitler, 2011, s. 23).

Przedmiotem poniższych refleksji są relacje, jakie zachodzą lub potencjalnie mogą zachodzić pomiędzy radykalną myślą polityczną, której akolitami są aktywne ruchy i partie nacjonalistyczne i antysystemowe oraz demokracją, podstawę której stanowią wartości, takie jak wolność, pluralizm i tolerancja. Celem jest natomiast wskazanie obszarów zagrożeń dla demokratycznego państwa prawa, które mogą być powodowane przez radykalny nacjonalizm i radykalnych nacjonalistów. Te zagrożenia mogą przybrać zarówno wewnętrzny (wewnątrzpaństwowy), jak i zewnętrzny wymiar, co stanowi hipotezę badawczą. W celu jej weryfikacji została zastosowana metoda analizy tekstów źródłowych oraz przejawów aktywności ruchów społecznych i partii politycznych o predylekcjach antysystemowych motywowanych nacjonalizmem.

\section{Pluralizm eksplanacyjny terminu ,nacjonalizm”}

Nacjonalizm nie jest interpretowany jednoznacznie. Wyjaśnienia tego terminu różnią się przede wszystkim stosunkiem podmiotów wyjaśniających do narodu i jego historycznej roli. Wpływ na akcentowanie poszczególnych elementów nacjonalizmu mają także teorie wyjaśniające pierwszeństwo bądź wtórność narodu lub nacjonalizmu, a także różnice obszarów geograficzno-kulturowych, szczególnie różnice pomiędzy Europą Zachodnią i Europą Wschodnią. Encyclopaedia Britannica definiuje nacjonalizm jako ideologię opartą na założeniu, że „lojalność jednostki i przywiązanie do państwa narodowego przewyższają inne interesy indywidualne lub grupowe" (Kohn, 2018). Z kolei Encyklopedia PWN definiuje nacjonalizm jako ,przekonanie, że naród jest najważniejszą formą uspołecznienia, a tożsamość narodowa najważniejszym składnikiem tożsamości jednostki, połączone z nakazem przedkładania solidarności narodowej nad wszelkie inne związki i zobowiązania oraz wszystkiego, co narodowe, nad to, co cudzoziemskie lub kosmopolityczne". To także ideologia polityczna, według której ,podstawowym zadaniem państwa jest obrona interesów narodowych, a jego zasięg terytorialny winien odpowiadać obszarom zamieszkanym przez dany naród" (Encyklopedia PWN, 2018). Z kolei nacjonaliści - np. z Brytyjskiej Partii Narodowej (British National Party) zdefiniowali nacjonalizm jako coś więcej niż ideologię. Według nich nacjonalizm uznaje naród za najwyższą możliwą formę rozwoju społeczności opartą na demokracji - przy czym naród to dla nich ludzie i społeczności złączone wspólną kulturą, historią i pochodzeniem. Według Brytyjskiej Partii Narodowej, większe jednostki organizacyjne są nieorganiczne, nienaturalne i sprzyjają tyranii. Natomiast mniejsze nie mają zasobów, aby osiągnąć coś poza samym istnieniem. Dlatego państwo narodowe jest według nacjonalistów politycznym wyrazem woli ludzi do jedności, zachowania tożsamości, samorządu i wolności. Stanowi także równowagę między pragnieniem jedności i potrzebą przynależności z jednej strony, a indywidualną wolnością i niezależnością z drugiej. Jest ,rodziną rodzin” (British National Party, 2013). Dla polskich nacjonalistów z Obozu Narodowo-Radykalnego naród jest trwa- 
łą, organiczną wspólnotą kulturową pokoleń przeszłych, obecnych i przyszłych oraz najwyższą wartością doczesną (Obóz Narodowo-Radykalny, 2018). Natomiast dla Narodowego Odrodzenia Polski naród jest wspólnotą naturalną oraz „dobrowolnym, opartym na więzi psychicznej i moralnej związkiem ludzi posiadających - wynikające ze wspólnych przodków i historycznej tradycji - poczucie odrębności kulturowej i chęć jej zachowania oraz rozwoju" (Narodowe Odrodzenie Polski, 2018). Z kolei przeciwnicy nacjonalizmu traktują go jako ideologię dyskryminującą grupy społeczne inne niż narody i fałszywie uznającą wspólne interesy grup narodowych. Według nich idee nacjonalistyczne służą klasie rządzącej, będąc narzędziem podziału społeczeństwa i podtrzymania dominacji elit (Federacja Anarchistyczna, 2018).

Nacjonalizm może być elementem pluralistycznego ideowo społeczeństwa, zwłaszcza jeśli jest interpretowany nieemocjonalnie i niepejoratywnie. Może mieć jednak także charakter antysystemowy, wówczas kiedy podważa zasady demokratycznego państwa prawa. Demokracja to określone prawem wolności obywatelskie, wybory legitymizujące pochodzenie władzy, kontrola społeczna nad rządzącymi, rotacja rządzących i tolerancja dla ludzi inaczej myślących, a także adekwatny typ mentalności społecznej, nawyki, obyczaje i spontaniczna aktywność obywatelska, pluralizm oraz uzgadnianie zróżnicowanych interesów i poglądów, a także policentryzm, rozdzielający i równoważący ośrodki kierownicze w różnych dziedzinach życia społecznego (Karwat, 2005, s. 50-62). Jeśli ruchy społeczne bądź partie polityczne o predylekcjach nacjonalistycznych podważają te zasady, można uznać je za antysystemowe.

Takie partie i ruchy stanowić mogą zagrożenie dla demokratycznego państwa prawa. Zagrożenie to może przybrać dwa wymiary: wewnętrzny i zewnętrzny.

\section{Wewnętrzny wymiar zagrożeń dla demokracji}

Zagrożenia wewnętrzne dotyczą zasad konstytucyjnych, które podważane mogą być przez myśl i działalność antysystemową. Poszczególne państwa demokratyczne w swoich systemach prawnych wprowadzily uregulowania, które zakresem przedmiotowym obejmują programy i aktywność organizacji antysystemowych. W Polsce do problemu tego odnosi się artykuł 13. Konstytucji Rzeczypospolitej Polskiej, zgodnie z którym: „Zakazane jest istnienie partii politycznych i innych organizacji odwołujących się w swoich programach do totalitarnych metod i praktyk działania nazizmu, faszyzmu i komunizmu, a także tych, których program lub działalność zakłada lub dopuszcza nienawiść rasową i narodowościową, stosowanie przemocy w celu zdobycia władzy lub wpływu na politykę państwa albo przewiduje utajnienie struktur lub członkostwa" (Konstytucja Rzeczypospolitej Polskiej, 1997). W Republice Federalnej Niemiec kwestie te uregulowano bez odwoływania się do skonkretyzowanych nurtów myśli politycznej i przejawów aktywności antysystemowej uznając, że samo nadużywanie praw demokratycznych jest podstawą do utraty tych praw. Problem ten reguluje artykuł 18. Ustawy Zasadniczej, w myśl którego: „Kto nadużywa prawa do swobodnego wyrażania poglądów, zwłaszcza wolności prasy (art. 5 ust. 1), wolności nauczania (art. 5 ust. 3), wolności zgromadzeń (art. 8), wolności zrzeszania się (art. 9), tajemnicy korespondencji, przesyłek pocztowych i telekomunikacji (art. 10), własności (art. 14) 
lub prawa do azylu (art. 16 a) w celu walki przeciw podstawom porządku wolnościowo-demokratycznego, prawa te traci. O utracie praw i jej wymiarze orzeka Federalny Trybunał Konstytucyjny" (Ustawa Zasadnicza, 2010). Już jednak artykuł 9. precyzuje: „Zakazuje się tworzenia stowarzyszeń, których cele i działalność są sprzeczne z przepisami prawa karnego lub skierowane przeciwko porządkowi konstytucyjnemu lub idei porozumienia między narodami” (Ustawa Zasadnicza, 2010). Z kolei zapis artykułu 21. Ustawy Zasadniczej zbliżony jest merytorycznie do treści artykułu 13. Konstytucji Rzeczypospolitej Polskiej: „Partie polityczne, których cele lub działalność ich zwolenników ukierunkowane są na podważanie lub obalenie wolnościowo-demokratycznych zasad ustroju lub zagrażają istnieniu Republiki Federalnej Niemiec, są niezgodne z Konstytucją. Decyzję o niezgodności z konstytucją podejmuje Federalny Trybunał Konstytucyjny" (Ustawa Zasadnicza, 2010). W innych państwach europejskich istnieją także przepisy zakazujące działalności antysystemowych grup politycznych, nie zawsze jednak umieszczone były na poziomie konstytucyjnym. Przykład Polski i Niemiec jest przykładem państw dotkniętych w przeszłości totalitaryzmami, co stanowiło jedną z przyczyn uregulowania tych kwestii na najwyższym poziomie systemu prawa.

Nie zmienia to jednak faktu, że organizacje polityczne o charakterze antysystemowym działały współcześnie i w przeszłości zarówno w tych państwach, jak i w innych regionach Europy. W Niemczech jedną z tego typu partii jest Narodowodemokratyczna Partia Niemiec (Nationaldemokratische Partei Deutschlands, NPD). To partia, która powstała w 1964 roku, wobec której kilkukrotnie podejmowane były bezskuteczne próby delegalizacji (Moroska, 2011, s. 155-176; Scheffler, 2015, s. 89-103; Baran, 2011, s. 201-208; Tujdowski, 2012, s. 1-4). W Polsce działało m.in. Narodowe Odrodzenie Polski, które jako ruch społeczny powstało w latach osiemdziesiątych XX wie-

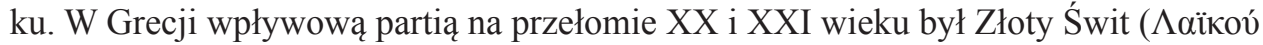

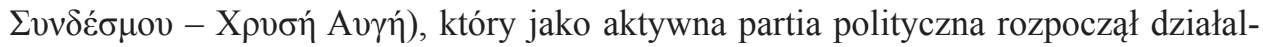
ność na początku lat dziewięćdziesiątych XX wieku. Na Ukrainie działał od 2013 roku Prawy Sektor (Правий сектор). We Włoszech w 1997 roku powstała Nowa Siła (Forza Nuova). To tylko wybrane przykłady partii politycznych, które swoje programy uzasadniały nacjonalizmem, i których deklaracje ideowe oraz aktywność potwierdzały ich antysystemowy charakter. Wśród partii nacjonalistycznych w Europie wymienić należy także takie ugrupowania, jak np. Narodowa Demokracja (Democracia Nacional) z Hiszpanii, Związek Narodowców (Tautininkų sajunga) z Litwy, Partia Narodowego Odrodzenia (Partido Nacional Renovador) z Portugalii, Serbska Partia Radykalna (Српска радикална странка) z Serbii, Partia Ludowa Nasza Słowacja (L'udová strana Naše Slovensko) ze Słowacji, Wszechukraińskie Zjednoczenie „Swoboda” (Всеукраїнське об’єднання „Свобода”) z Ukrainy, Brytyjska Partia Narodowa (British National Party) z Wielkiej Brytanii. Niektóre z nich korzystają z praw demokratycznych i współtworzą parlamenty krajowe oraz Parlament Europejski. Należy wspomnieć ponadto o ugrupowaniach nacjonalistycznych z Walii, Szkocji, Irlandii, Austrii, Turcji, Belgii, Rumunii, Albanii, Bułgarii, o innych polskich organizacjach i partiach nacjonalistycznych, o wielości partii i organizacji nacjonalistycznych z Rosji, Włoch czy Hiszpanii, czy też o nacjonalistach regionalnych np. z Kraju Basków, Katalonii, Kornwalii, Galicji czy też Walencji. Nie wszystkie z nich miały charakter 
antysystemowy, choć wszystkie uzasadniały swoją myśl polityczną ideami nacjonalistycznymi (Malendowicz, 2017).

Niemiecka NPD swój program z 2010 roku oparła na zasadach programowych, których podstawą były idee nacjonalizmu. NPD odrzuciła wielokulturowość państwa niemieckiego, amerykanizację i islamizację. Dla tej partii suwerenność narodowa to odbudowa niemieckiej państwowości i możliwość wystąpienia z ponadnarodowych instytucji, takich jak Unia Europejska i NATO. Partia sprzeciwiała się globalizacji. Podkreślała znaczenie rodziny, którą uznała za podstawę narodu, a więc sprzeciwiała się wsparciu dla związków nieheteroseksualnych. Jedna z części programu została zatytułowana Niemcy dla Niemców. NPD przestrzegała, że w wielu miastach powstają społeczeństwa równoległe i getta cudzoziemców, gdzie pozostali członkowie niemieckiej społeczności stali się mniejszością we własnym kraju. Domagała się rozwiązań legislacyjnych zmierzających do wydalenia cudzoziemców przebywających na terenie Niemiec. Podstawą niemieckiej polityki imigracyjnej powinien być bowiem obowiązek powrotu zamiast prawa do pozostania na terenie kraju (Nationaldemokratische Partei Deutschlands, 2014).

W Polsce, Narodowe Odrodzenie Polski kreowało się na formę obywatelskiego oporu wobec „zbiurokratyzowanego państwa demoliberalnego”. Deklarowało, że „nie działa na rzecz naprawy istniejącego ustroju, gdyż nie da się uratować rudery, trzymającej się w całości jedynie dzięki żelaznym obręczom ekonomicznego ucisku i policyjno-politycznych represji” (Narodowe Odrodzenie Polski, 2016). Partia dążyła do budowy nowego ładu politycznego i gospodarczego. Jej krytyka demokracji i kapitalizmu miała zatem wymiar substancjalistyczny.

W Grecji partia Złoty Świt negowała komunizm i liberalizm proponując nową ideologię, która powinna służyć władzy mającej na celu stworzenie nowego społeczeństwa i nowego rodzaju człowieka. W państwie nacjonalistów panować miałaby absolutna równość wobec prawa oraz usankcjonowana politycznie równość społeczna. Według greckich nacjonalistów lud, a nie pojedyncza jednostka, ma znaczenie. Jednostki nie mają znaczenia historycznego (Golden Dawn, 2016). Program Złotego Świtu zawierał zatem elementy gnozy politycznej, co znaczy, że jego autorzy kreowali siebie na tych, którzy poznali jedyną prawdę o świecie i przyszłości narodu. Był to program absolutyzmu, czy wręcz totalizmu - paradoksalnie - w znaczeniu komunistycznym. Wreszcie miał charakter antyindywidualistyczny, wszak grupę ludzi (naród) przedkładał ponad jednostkę.

Na Ukrainie Prawy Sektor zaproponował nowy system władzy. Partia nazwała go narodokracją. W idealistycznej wizji narodokracji władza polityczna miałaby należeć do narodu i sprawowana byłaby za pośrednictwem jego najzdolniejszych, altruistycznych i ideowych przedstawicieli. Nacjonaliści zaproponowali reformę systemu politycznego, wprowadzenie mechanizmu wycofywania parlamentarzystów, ograniczenia immunitetu parlamentarnego i impeachmentu (Програма партії „Правий сектор”, 2016). Program ten stanowił paradoks, który z jednej strony przejawiał się w idealizowaniu narodu poprzez deklarowane dlań zaufanie i koncepcję narodokracji, a z drugiej strony rzeczywistą władzę powierzał najzdolniejszym i ideowym przedstawicielom narodu, wyrażając tym samym brak zaufania do narodu, który przecież mógłby okazać się niedojrzały, nie dość altruistyczny, czy wręcz niewystarczająco „narodowy”. 
Włoska Nowa Siła żądała zniesienia prawa, zgodnie z którym karana jest propaganda faszystowska. Postulat ten dotyczył ustawy z 1993 roku, w myśl której zakazane są m.in. gesty faszystowskie oraz hasła popierające dyskryminację rasową i etniczną. Parita twierdziła, że działania na rzecz zniesienia prawa są formą obrony włoskiej historii i kultury (Forza Nuova, 2016).

To wybrane przykłady antysystemowości myśli politycznej partii i organizacji uzasadniających swoje programy nacjonalizmem, która jest antagonistyczna wobec zasad stanowiących fundament demokratycznego państwa prawa.

Myśl polityczna nie powstaje jednak w próżni, a jej analiza dokonana w separacji od jej przejawów naznaczona byłaby błędem. Dlatego też należy wskazać, że partie oraz organizacje lub ich członkowie i zwolennicy demonstrowali swoją antysystemowość nie tylko poprzez słowa programów politycznych, ale także działalność i konflikty z prawem.

W Polsce aktywność motywowana nacjonalizmem lub rasizmem dokumentowana jest przez Stowarzyszenie Nigdy Więcej w ramach publikowanych także w Internecie Brunatnych Ksiag (Stowarzyszenie Nigdy Więcej, 2018). W nich wymieniane są akty przemocy na tle narodowym i rasistowskim, przejawy mowy nienawiści i innych zachowań stanowiących konflikty z prawem.

We Włoszech liderem Nowej Siły był Roberto Fiore, późniejszy poseł do Parlamentu Europejskiego. W 1980 roku zbiegł on z Włoch do Wielkiej Brytanii w związku z oskarżeniem dotyczącym zamachu terrorystycznego, który został zorganizowany przez jedno z włoskich ugrupowań faszystowskich. W Wielkiej Brytanii został aresztowany, ale nie doszło do jego ekstradycji do Włoch. W tym czasie toczył się proces sądowy w jego sprawie we Włoszech, w którym został skazany na karę więzienia za udział w organizacji wywrotowej (Cobain, Taylor, 2008).

W Grecji w 2013 roku miało miejsce zabójstwo muzyka Pavlossa Fyssasa, który przed śmiercią miał wskazać mordercę, którym był jeden z działaczy Złotego Świtu. W następstwie tego wydarzenia aresztowano kilkudziesięciu członków partii, w tym jej przewodniczącego Nikolaosa Michaloliakosa. Zostali oni oskarżeni o udział w zorganizowanej grupie przestępczej (Grecja, 2015).

W Serbii na czele Serbskiej Partii Radykalnej stał Vojislav Šešelj, który został oskarżony o zbrodnie wojenne i zbrodnie przeciwko ludzkości. Został uniewinniony w 2016 roku przez Międzynarodowy Trybunał Karny ds. byłej Jugosławii w Hadze (IAR/jż, 2015; Serbska, 2016).

\section{Zagrożenia zewnętrzne dla demokracji}

Zagrożenia dla demokracji, których przejawem jest myśl polityczna i jej symptomaty wewnątrz państw demokratycznych, w tym także akty przemocy i innego rodzaju konflikty z prawem, nie są jedynymi zagrożeniami. Innego rodzaju wymiar mają zagrożenia zewnętrzne. To zagrożenia wobec innych państw, które mogą stwarzać państwa, w których antysystemowa myśl polityczna jest realizowana. Zagrożenia tego rodzaju mogą być powodowane przez ugrupowania (i ich akolitów), które mają znaczące poparcie społeczne, przez partie, które przejęły władzę, a także partie, które 
mają poparcie marginalne, ale ich poziom aktywności, zwłaszcza w określonych regionach, przewyższa aktywność innych partii politycznych.

Ostatni rodzaj zagrożeń dotyczy szczególnie regionów przygranicznych. W Niemczech na pograniczu polsko-niemieckim przestępczość skrajnej prawicy wzrosła szczególnie od 2006 roku, a „liderem” w tym względzie był Frankfurt nad Odrą. Aktywność NPD mierzona była w polskich obywateli osiedlających się po niemieckiej stronie granicy. Niemiecka skrajnie prawicowa opozycja antysystemowa prowadziła na pograniczu akcje ulotkowe, plakatowe i organizowała punkty informacyjne oraz demonstracje. Podczas demonstracji nawoływano m.in. do przywrócenia kontroli granicznej na granicy z Polską i do powstrzymania polskiej przestępczości w Niemczech. Z kolei w Meklemburgii temat Polaków i ,polskiej inwazji” w drugiej dekadzie XXI wieku stał się „dyżurnym tematem” w przekazie lokalnych struktur NPD. Prowadzono tam antypolskie akcje plakatowe i ulotkowe, ale w poprzednich latach dochodziło do poważniejszych incydentów (np. demolowania polskich samochodów, zamalowywania polskich nazwisk na domofonach). Również saksońskie struktury NPD organizowały antypolskie akcje propagandowe (np. głośna akcja antypolskich plakatów w Görlitz, która jednak spotkała się ze zdecydowanym oporem innych mieszkańców miasta) (Tujdowski, 2012, s. 3).

Poza aktywnością zwolenników NPD, w swoim programie partia ta głosi radykalne postulaty kwestionujące współczesny ład międzynarodowy. NPD domagała się realizowania polityki zjednoczenia Niemiec przy uwzględnieniu obszarów „historycznie przynależnych" do Niemiec. Żądała udzielenia pomocy Niemcom przebywającym na terenach poza obszarem kraju w kwestii zachowania ich niemieckiej kultury oraz tożsamości. Obowiązkiem państwa miało być wspieranie związków „wypędzonych” w realizacji ich interesów oraz kultywowaniu pamięci o niemieckiej ojczyźnie w miejscu obecnego zamieszkania - „terenach okupowanych”. Partia ta chciała, aby niemiecki rząd pomagał potomkom „wypędzonych” w odzyskaniu mienia, które przepadło na rzecz np. Polski. Wzywała do zakończenia pielęgnowania „kultu winy” narodu niemieckiego, związanego z okresem nazizmu i II wojny światowej. Uznała, że dzień 8 maja 1945 roku nie był dniem wyzwolenia, ale symbolem klęski i okupacji kraju (Nationaldemokratische Partei Deutschlands, 2014).

NPD określała obszar byłej Niemieckiej Republiki Demokratycznej (NRD) jako „Środkowe Niemcy”, co oznacza, że wschodnie Niemcy leżą na terenie Polski. To kwestionowanie powojennego ładu międzynarodowego, w tym systemu granic państwowych (Nationaldemokratische Partei Deutschlands, 2014). Jeden z istotnych działaczy NPD Udo Pastörs stwierdził w 2006 roku, że umów pokojowych po II wojnie nie podpisał suwerenny rząd Niemiec, ale ,marionetkowy reżim ustanowiony przez amerykańskich okupantów”, dodając, że „Na razie Polska z Niemcami ma jedynie zawieszenie broni. Między naszymi krajami nie został podpisany żaden ważny traktat międzynarodowy. Stan wojny trwa" (Sterlingow, Wąs, 2006, s. 2). Tego typu słowa mogą wywoływać nie tylko lęk, ale i strach przed wojną, której skutecznym „neutralizatorem" może być projekt integracji europejskiej. Temu ostatniemu NPD wyraźnie sprzeciwia się.

Ukraińscy nacjonaliści z Wszechukraińskiego Zjednoczenia „Swoboda” wysuwali pretensje do regionu określanego mianem Zakerzonie. Region ten to obszar od Bia- 
łej Podlaskiej na północy, przez Włodawę, Horodło, Rzeszów, Jasło, Przemyśl, do Ustrzyk Dolnych na południu (Ukraiński, 2016). Nie był jasny także stosunek litewskich nacjonalistów do kwestii przynależności terytorialnej regionu Suwalszczyzny. Także i niektórzy polscy nacjonaliści upominali się o polski Lwów i polskie Wilno.

Współczesny ład międzynarodowy kwestionowany był również przez Serbską Partię Radykalną. Partia ta wzywała do zjednoczenia ziem serbskich podzielonych po rozpadzie Jugosławii. Zjednoczenie narodu serbskiego miało objąć Republikę Serbii, Czarnogórę i Republikę Serbskiej Krajiny (nieuznawane państwo istniejące w latach 1991-1995). Tak miała powstać „Wielka Serbia” (Програм Српске радикалне странке, 2015). Podobne koncepcje, w odniesieniu do Albanii, wysuwali nacjonaliści z tego państwa, postulując powstanie „Wielkiej Albanii”. To charakterystyczny postulat nacjonalistów również z innych państw, zwłaszcza tego regionu kontynentu.

Specyficzny rodzaj zagrożeń dla demokracji środkowo- i zachodnioeuropejskich oraz ładu międzynarodowego stanowi rosyjskie myślenie politycznego marginesu, które nie pozostaje bez wpływu na myśl polityczną dominującą w Rosji. Opiera się ono na natywistycznych i kontrakulturacyjnych postawach wobec kultury dominującej (zachodniej). Natywizm jest świadomym dążeniem do odnowy lub uwiecznienia wybranych aspektów własnej kultury. Odnosi się do kultury zniszczonej lub ulegającej zniszczeniu. Kontrakulturacja to natomiast negacja i dążenie do wytępienia obcej kultury, w formie agresywnej, w fantazji lub realnie (Bäcker, 2007, s. 21-25).

Rosyjskie organizacje i partie polityczne, działające na przełomie XX i XXI wieku, których programy motywowane były nacjonalizmem, to wielość struktur, wśród których wymienić można takie, jak m.in.: Partia „Ојсzуzna” (Партия „Родина”), Rosyjski Związek Ludowy (Российский общенародный союз), Partia NarodowoDemokratyczna (Национально-Демократическая Партия), Zjednoczenie Rosyjskie Etniczno-Polityczne (Этнополитическое Объединение Русские), Wielka Rosja (Великая Россия), Sobór Narodowy (Народный собор), Rosyjski Ruch Imperialny (Русское Имперское Движение), Sobór Narodu Rosyjskiego (Собор русского народа), Partia Ochrony Rosyjskiej Konstytucji „Ruś” (Партия защиты российской Конституции „Русь”), Rosyjski Ruch Narodowo-Patriotyczny (Русское Националпатриотическое движение), Opór (Сопротивление), Inicjatywa Narodowa Socjalistyczna (Национальная Социалистическая Инициатива), Restrukt (Реструкт), Awangarda Czerwonej Młodzieży (Авангард Красной Молодежи), Narodowe Pospolite Ruszenie im. Minina i Pożarskiego (Народное ополчение имени Минина и Пожарского), Inna Rosja (Другая Россия), Partia Narodowo-Bolszewicka (Национал Большевистская Партия), Armia Woli Narodu (Армия воли народа), Rosyjski Front Oswobodzenia „Раmięci” (Русский Фронт Освобождения „Память”), Rosyjska narodowa jedność - Gwardia Barkaszowa (Русское национальное единство - Гвардия Баркашова), Wszechrosyjski Ruch Społeczno-Patriotyczny „Rosyjska Narodowa Jedność" (Русское национальное единство), Ruch Aleksandra Barkaszowa (Движение „Александр Баркашов”), Narodowo-Mocarstwowa Partia Rosji (Национально-державная партия России), Partia Narodowo-Ludowa (Народная национальная партия), Prawdziwa Rosyjska Jedność Narodowa (Истинное русское национальное единство), Bałtycka Awangarda Rosyjskiego Oporu (Балтийский Авангард Русского Сопротивления), Rosyjski Zjednoczony Narodowy Alians 
(Русский объединённый национальный альянс), Gwardia Chrystusa (Гвардия Христа), Narodowe Zjednoczenie (Национальный союз - HC), Unia Prawosławnych Chorągwienosców (Союз православных хоругвеносцев), Sojusz Rosyjskiego Narodu (Союз русского народа), Bractwo Północne (Северное братство), Czarna Sotnia (Чёрная Сотня), Ruch Parabellum (Движение Парабеллум), Nacjonalno-Socjalistyczna Partia Rusi (Национал-социалистическая партия Руси), Partia Swobody (Партия Свободы), Rosyjski Obraz (Русский Образъ), Nacjonalistyczno-Syndykalistyczna Ofensywa (Национал-синдикалистское наступление) (Lista, 2014; zob. Bäcker, 2007, s. 130-162; Diec, 2010, s. 349-377; Malendowicz, 2017, s. 134-157). Niektóre z nich miały charakter antysystemowy, narodowo-socjalistyczny, faszystowski, narodowo-komunistyczny albo narodowo-bolszewicki. Cechował je programowy antyokcydentalizm. W tym kontekście należy wymienić również działające w Rosji ruchy nacjonalistów indywidualistów, organizacje antyimigranckie, nacjonalistycznych pisarzy wiejskich czy też grupy skupione wokół nacjonalistów i antyokcydentalistów takich, jak np. zmarły w 2008 roku Aleksander Sołżenicyn (Bäcker, 2008, s. 169-206). Myśl polityczną opartą na nacjonalizmie rosyjskim cementował m.in. mit ojczyzny, który uzasadniał wielkość Rosji i jej ingerencję w sprawy innych państw, w połączeniu z odwoływaniem się do mitu narodu, historycznej potęgi Rosji, wyobrażonych bądź rzeczywistych zagrożeń ze strony wrogów zewnętrznych oraz potrzeby silnego przywódcy narodu i państwa (Timofiejuk, 2004, s. 47-62).

\section{Konkluzje}

Wewnętrzny wymiar zagrożeń dla demokratycznych państw prawa ze strony ruchów antysystemowych może być analizowany w aspekcie zagrożeń niedokonanych i dokonanych (realizowanych i zrealizowanych). Programy niedokonane organizacji i partii radykalnych wskazują nie tylko zagrożenia dla demokracji, ale także jej wady, do których zaliczyć można np. alienację elit politycznych, „odpływ” władzy od suwerena (narodu), materialną polaryzację społeczeństw powodowaną nierównomiernym rozdziałem dochodu narodowego, nierówny dostęp do zasobów, ścieżek rozwoju i przywilejów. Partie i organizacje radykalne oraz populistyczne bazują na wymienionych deficytach, dążąc do wpływu na władzę i do przejęcia władzy. Jednakże radykalizm zrealizowany może okazać się zaprzeczeniem deklarowanych programów narodowładztwa z uwagi na ich absolutyzm i fundamentalizm interpretacyjny, który przejawia się w bezkompromisowości i pryncypialności traktowania elementarnych zasad nacjonalizmu, który przybiera postać myśli antysystemowej. Programy te wyróżnia także antyindywidualizm i totalizm zbiorowości. Radykalizm realizowany w aspekcie wewnętrznym wpływać może z kolei na zewnętrzny wymiar zagrożeń dla demokracji. Staje się agresywny - nie może bowiem przetrwać w otoczeniu państw demokratycznych. Napędza go mit wroga, który upowszechniany w imię interesu elit nowej władzy, podważa stabilność ładu międzynarodowego.

Istnieje jednakże panaceum minimalizujące radykalizm polityczny i zagrożenia zeń wynikające. Jest nim przezwyciężenie lub choćby redukcja wad demokracji, na których bazują ruchy antysystemowe - tak rewolucyjnej lewicy, jak i dalekiej prawi- 
cy. To konieczność upowszechniania rozumnej wiedzy i kultury, tak aby współczesny człowiek przestał być nieświadomym i biernym trybem w maszynie kierowanej przez demagogów oraz anonimowe elity polityczne, korporacyjne i finansowe. Aby rzeczywista władza przestała być domeną nieidentyfikowalnych elit projektujących świat zgodnie ze swoją wolą, nie zaś wolą świadomych i wyedukowanych społeczeństw. To potrzeba kształtowania mentalności i obyczajowości demokratycznej, gdzie aspiracje indywidualne są koherentne $\mathrm{z}$ działaniami wspólnotowymi i nie zaprzeczają sobie wzajemnie. To wymóg powrotu do świadomej aktywności społeczeństw i idei społeczeństwa obywatelskiego. To konieczność upowszechniania instytucji i procedur demokracji. To wreszcie konieczność minimalizacji materialnych dysproporcji wewnątrz społeczeństw i między nimi, z naciskiem na rozwój stanu średniego, który winien stanowić fundament demokratycznego państwa i społeczeństwa dobrobytu.

\section{Bibliografia}

Bäcker R. (2007), Rosyjskie myślenie polityczne za czasów prezydenta Putina, Wydawnictwo Adam Marszałek, Toruń.

Bäcker R. (2008), Współczesne rosyjskie nacjonalizmy, w: Współczesne nacjonalizmy, red. M. Jeziński, Wydawnictwo Adam Marszałek, Toruń.

Baran Ł. (2011), Niemieckie partie dalekiej prawicy na poziomie lokalnym w Meklemburgii i Saksonii, „Ogrody Nauk i Sztuk”, nr 1.

Bartyzel J. (2009), Śmiertelny bóg Demos. Pięć wyktadów o demokracji i jej krytykach, Fijorr Publishing, Warszawa.

British National Party, Nationalism - A definition, 3.05.2013, http://www.bnp.org.uk/news/national/ nationalism-definition, 31.08.2016.

Cobain I., Taylor M., Language school run by Italian fascist leader, 29.02.2008, https://www.theguardian.com/politics/2008/feb/29/thefarright.italy, 4.12.2016.

Diec J. (2010), Główne nurty nacjonalizmu rosyjskiego, w: Różne oblicza nacjonalizmów. Polityka - religia - etos, red. B. Grott, Nomos, Kraków.

Encyklopedia PWN, Nacjonalizm, https:/encyklopedia.pwn.pl/haslo/nacjonalizm;3945094.html, 4.04.2018.

Federacja Anarchistyczna, Ptaszczyzna ideowa, http://www.federacja-anarchistyczna.pl/index.php/ plaszczyzna, 4.04.2018.

Forza Nuova, 8 Punti, http://www.forzanuova.eu/?page_id=542, 4.12.2016.

Golden Dawn, What Being a Golden-Dawner Means, http://www.xryshaygh.com/en/information, 28.06.2016.

Grecja: Ruszyt proces działaczy Złotego Świtu, 7.02.2015, http://autonom.pl/?p=11053, 14.01.2017.

IAR/jż, Vojislav Šešelj odmówił powrotu z Serbii do Holandii, 30.03.2015, http://www.polskieradio.p1/5/3/Artykul/1410563,Vojislav-\%C5\%A0e\%C5\%A1elj-odmowil-powrotu-z-Serbiido-Holandii, 11.10.2016.

Karwat M. (2005), Kryteria demokratyzmu postaw społecznych, stosunków politycznych i państwa, „Społeczeństwo i Polityka”, nr 1 (2).

Kitler W. (2011), Bezpieczeństwo narodowe RP. Podstawowe kategorie, uwarunkowania, system, Akademia Obrony Narodowej, Warszawa.

Kohn H., Nationalism, 9.03.2018, https:/www.britannica.com/topic/nationalism, 4.04.2018.

Konstytucja Rzeczypospolitej Polskiej z dnia 2 kwietnia 1997 r., Dz. U. 1997, Nr 78 poz. 483. 
Lista rosyjskich nacjonalistycznych i faszystowskich partii oraz organizacji, 7.06.2014, http://nawschododbuga.blog.p1/2014/06/07/lista-rosyjskich-nacjonalistycznych-i-faszystowskichpartii-oraz-organizacji/, 28.11.2016.

Malendowicz P. (2017), W drodze do władzy... Nacjonalistyczne projekty państw Europy XXI wieku, Wąbrzeskie Zakłady Graficzne, Bydgoszcz.

Moroska A. (2011), Delegalizacja partii politycznych jako instrument bezpieczeństwa wewnętrznego państwa. Analiza na przykładzie Niemiec, „Rocznik Bezpieczeństwa Międzynarodowego”, vol. 5.

Narodowe Odrodzenie Polski, Zasady ideowe nacjonalizmu, http://www.nop.org.pl/zasady-ideowenacjonalizmu/, 4.04.2018.

Narodowe Odrodzenie Polski, Zasady programowe, http://www.nop.org.pl/zasady-programowe/, 2.12.2016.

Nationaldemokratische Partei Deutschlands, Arbeit. Familie. Vaterland. Das Parteiprogramm der Nationaldemokratischen Partei Deutschlands, http://www.npd.de/themen/, 9.12.2014.

Obóz Narodowo-Radykalny, Nowa deklaracja ideowa, https://www.onr.com.pl/deklaracja-ideowa/, 4.04.2018.

Olszewski E. (2000), Ruch społeczny, w: Encyklopedia politologii, red. M. Żmigrodzki, t. IV: Myśl społeczna i ruchy polityczne wspólczesnego świata, red. M. Marczewska-Rytko, E. Olszewski, Kantor Wydawniczy Zakamycze, Kraków.

Paruch W. (1999), Myśl polityczna - refleksje metodologiczne o pojęciu, „Annales Universitatis Mariae Curie-Skłodowska Lublin - Polonia, Sectio K”, vol. VI.

Scheffler T. (2015), Ekstremizm polityczny: nieudana próba delegalizacji Narodowodemokratycznej Partii Niemiec (NPD) w latach 2001-2003 i jej znaczenie dla polskiego porzadku prawnego, „Studia nad Autorytaryzmem i Totalitaryzmem”, 37, nr 3.

Serbska Partia Radykalna, 13.08.2016, http://www.dzienniknarodowy.p1/2154/serbska-partia-radykalna/, 16.01.2017.

Sterlingow M., Wąs M., Herbatka z nazista, „Gazeta Wyborcza” z dnia 23.10.2006 r., dodatek „Duży Format".

Stowarzyszenie Nigdy Więcej, Brunatna Księga, http:/www.nigdywiecej.org/brunatna-ksiega, 7.04.2018.

Sztompka P. (2005), Socjologia. Analiza społeczeństwa, Wydawnictwo Znak, Kraków.

Timofiejuk P. (2004), Mity nacjonalistów rosyjskich, w: Narody i nacjonalizm w Federacji Rosyjskiej, red. P. Timofiejuk, A. Wierzbicki, E. Zieliński, Dom Wydawniczy Elipsa, Warszawa.

Tujdowski M. (2012), Próba delegalizacji skrajnie prawicowej Narodowodemokratycznej Partii Niemiec (NPD) - polski punkt widzenia, „Biuletyn Instytutu Zachodniego”, nr 112.

Ukrainski parlament pracuje nad ustawa uznajaca Polske za okupanta Chetma, Przemyśla $i$ Rzeszowa, 12.11.2016, http://zmianynaziemi.pl/wiadomosc/ukrainski-parlamentpracuje-nad-ustawa-uznajaca-polske-za-okupanta-chelma-przemysla-i, 17.01.2017.

Ustawa Zasadnicza dla Republiki Federalnej Niemiec (2010), przekład A. M. Sadowski, Deutscher Bundestag, Berlin.

Програм Српске радикалне странке, http://www.srpskaradikalnastranka.org.rs/program/44, 7.01.2015.

Програма партії „Правий сектор”, http://pravyysektor.info/programa.html, 22.09.2016.

\section{Streszczenie}

Głównym zagadnieniem artykułu jest radykalna myśl polityczna, analizowana w kontekście bezpieczeństwa współczesnych demokracji europejskich. W artykule problem ten jest anali- 
zowany na przykładzie programów partii i innych organizacji, które uzasadniają swoją myśl polityczną nacjonalizmem, np. Narodowodemokratyczna Partia Niemiec, Narodowe Odrodzenie Polski, Złoty Świt z Grecji, Nowa Siła z Włoch, Brytyjska Partia Narodowa, Prawy Sektor i Swoboda z Ukrainy oraz innych. Radykalne partie nacjonalistyczne podważają zasady współczesnych demokracji. Dążą do zmiany ładu międzynarodowego i granic państw w Europie, które istnieją od końca II wojny światowej. Zdaniem autora, jedynym skutecznym lekarstwem na radykalizm polityczny jest rozwój wiedzy o demokracji, rozwój społeczeństwa obywatelskiego, eliminowanie materialnych różnic między grupami społecznymi i rozwój klasy średniej w Europie.

Słowa kluczowe: nacjonalizm, Unia Europejska, radykalizm, demokracja

\section{Radical political thought and the safety of European democracies. An example of anti-system nationalism}

\section{Summary}

The main issue of this article is the radical political thought and the security of contemporary European democracies. In this article, this problem is analyzed on the example of programs of nationalist parties and other organizations, e.g. National Democratic Party of Germany, National Revival of Poland, Golden Dawn from Greece, New Force from Italy, British National Party, Right Sector and Svoboda from Ukraine and others. Radical nationalist parties undermine of the principles of modern democracies. They attempt to change the international order and change the borders of countries in Europe that exist since the end of World War II. According to the author, only the reduction of defects of democracy and the development of knowledge about democracy, the development of civil society, the elimination of material disparities between social groups and the development of the middle class in Europe, can be an effective remedy for political radicalism.

Key words: nationalism, European Union, radicalism, democracy 